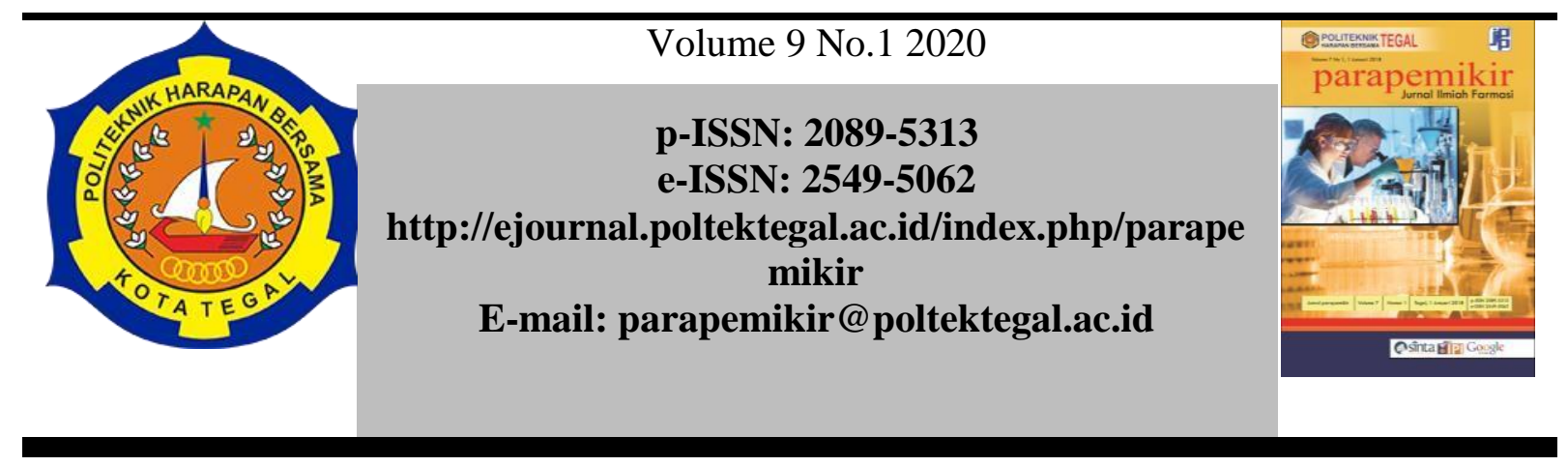

\title{
Aktivitas Antihiperurisemia Mikroenkapsulasi Ekstrak Kulit Melinjo (Gnetum gnemon L.) secara In Vivo
}

\author{
Dhimas Adhityasmara*1, Yustisia Dian Advistasari ${ }^{2}$, Bekti \\ Nugraheni $^{3}$ \\ Sekolah Tinggi Ilmu Farmasi "Yayasan Pharmasi Semarang" \\ e-mail: *1 dhimas.ep@gmail.com , \\ 2yusti.advistasari@gmail.com, ${ }^{3}$ bn.nugraheni@gmail.com
}

Article Info

Article history:

Submited September 2019

revised form

November 2019

Accepted December 2019

Published online

January 2020

\begin{abstract}
Abstrak
Hiperurisemia merupakan keadaan dimana terjadi peningkatan kadar asam urat di atas normal. Salah satu bagian tanaman yang memiliki potensi sebagai pengganti alternatif dari allopurinol adalah kulit Melinjo. Kulit Melinjo diketahui mengandung pigmen antosianin berwarna merah. Disamping sebagai pewarna, antosianin juga bersifat antioksidan karena termasuk golongan flavonoid yang efektif untuk inaktivasi radikal bebas dan peroksil. Antosianin jika disimpan dalam waktu yang lama memiliki kelemahan terkait ketidakstabilannya dan mudah terdegradasi selama penyimpanan. Salah satu cara untuk mengatasi masalah tersebut adalah dengan cara dilakukan pembuatan mikroenkasulasi. Enkapsulasi adalah suatu teknik untuk melapisi atau menyalut suatu bahan aktif dengan lapisan dinding polimer sehingga menghasilkan partikel kecil berukuran mikro ataupun nano. Penelitian ini dilakukan bertujuan untuk mengetahui aktivitas antihiperuresimia ekstrak kulit melinjo yang telah dibuat sediaan mikroenkapsulasi.

Tikus Jantan Galur wistar di bagi menjadi 5 kelompok, kelompok negatif (CMC Na 0,5\%), kelompok positif (Allopurinol 12,6 mg/kg BB), kelompok dosis $100 \mathrm{mg} / \mathrm{KgBB}$, kelompok $200 \mathrm{mg} / \mathrm{Kg}$ BB dan kelompok dosis $300 \mathrm{mg} / \mathrm{kgBB}$. Kadar asam urat diukur pada jam ke 0 kemudian hewan uji di induksi dengan Kalium Oksonat dosis 300mg/kgBB secara intraperitonel \& Jus Hati ayam secara peroral sebanyak 2,5 mL. Selang 1 jam hewan uji diukur kadar asam urat dan diberikan sesuai perlakuan tiap kelompoknya. Diukur kadar asam urat tikus pada jam ke 2 dan ke 4 secara enzimatik dengan menggunakan alat Microlab®.

Hasil penelitian menunjukan terjadi kenaikan kadar asam urat pada hewan uji setalah diberikan induksi kalium oksonat $300 \mathrm{mg} / \mathrm{KgBB}$ dan jus hati ayam 2,5 $\mathrm{mL}$. Pada jam ke 2 terjadi penurunan kadar asam urat namun tidak menunjukan perbedaan yang signifikan tiap kelompok $(p>0.05)$. Pada jam ke 4 terjadi penurunan kadar asam urat secara signifikan antar kelompok perlakuan. Dari hasil penelitian dapat disimpulkan bahwa mikroenkapsulasi Ekstrak Kulit Melinjo mempunyai aktivitas antihiperurisemia dengan dosis 200mg/kgBB yang merupakan dosis efektif dalam menurunkan kadar urat.
\end{abstract}

Kata kunci : Ekstrak Kulit Melinjo, Mikroenkapsulasi, Antihiperurisemia 


\begin{abstract}
Hyperuricemicis as an abnormally elevated uric acid level in the blood.Gnetumgnemon, locally known as Melinjo, is one of the Indonesian indigenous plantswhichcan be an alternative source of allopurinol. The peels of Gnetumgnemon, usually be wasted,contains red anthocyanin pigments possessing antioxidant activity owing toits potential for the inactivation of free radicals and peroxyls. However, the anthocyanin will chemically result incompound instability and is easily degraded during the period ofstorage. Encapsulation remains as one of the eminent formulation techniques usedto protect the active pharmaceutical compound through coating ofmainingredient with polymer forming smallersize of particles within micro tonano.This study was aimed at determining the Gnetumgnemonpeel extract in microencapsulated form in inducing antihyperuricemic activity. The male Wistar-strain rats wereused as subjects, groupedinto fivedifferent feeding treatments, i.e. negative group (carboxymethyl cellulose (CMC) Na 0.5\%), positive group (allopurinol $12.6 \mathrm{mg} / \mathrm{kg} \mathrm{BM}$ ), andthree doses groups(i.e. $100 \mathrm{mg} / \mathrm{kgBM}, 200 \mathrm{mg} / \mathrm{kg} \mathrm{BM}$, dose group $300 \mathrm{mg} / \mathrm{kg} \mathrm{BM}$ ). Uric acid levels were initially assessed for each group, then every test-animals werefedwith a dose of $300 \mathrm{mg} / \mathrm{kg} \mathrm{BM}$ of potassium oxonate intraperitoneally, and $2.5 \mathrm{~mL}$ of chicken liver juiceorally. An hour interval was given for the uric acid levels measurement for each group. The results showed an increase in uric acid levels after the subjectswere treated accordingly with potassium oxonate $300 \mathrm{mg} / \mathrm{kg}$ BM and $2.5 \mathrm{~mL}$ chicken liver juice. At the hour-2, there was a decrease in uric acid levels but showingno significant difference in everygroup ( $p>0.05$ ). The significant decrease among the groups was found at hour4and indicates that dose of $200 \mathrm{mg} / \mathrm{kgBM}$ is an effective dose in reducing uric acidlevels.
\end{abstract}

Keyword: Gnetumgnemonpeel extract, microencapsulation, antihyperuricemic

CC2020PoliteknikHarapanBersamaTegal

Alamat korespondensi:

Prodi DIII Farmasi Politeknik Harapan Bersama Tegal

Gedung A Lt.3. Kampus 1

Jl. Mataram No.09 Kota Tegal, Kodepos 52122

Telp. (0283) 352000

p-ISSN: 2089-5313

E-mail: parapemikir_poltek@yahoo.com

e-ISSN: 2549-5062 


\section{PENDAHULUAN}

Hiperurisemia merupakan keadaan yang menunjukkan terjadinya peningkatan kadar asam urat di atas normal, dengan nilai normal darah kurang dari $7 \mathrm{mg} / \mathrm{dL}$ untuk pria dan $6 \mathrm{mg} / \mathrm{dL}$ untuk wanita. Asam urat merupakan hasil akhir dari katabolisme purin. Dalam proses katabolisme purin tersebut xanthine oxidase (XO) mengkatalisis xanthine dan hypoxanthine menjadi asam urat (Haidari et al., 2009).

Allopurinol merupakan obat asam urat golongan urikostatik yang merupakan inhibitor kuat dari XO yang dapat menurunkan kadar asam urat, tetapi allopurinol memiliki efek samping seperti hepatitis, nefropati dan alergi sehingga perlu adanya pencarian inhibitor XO yang baru dari sumber alam sebagai pengganti alternatif dari allopurinol (Haidari et al., 2009). Salah satu tanaman yang memiliki potensi sebagai pengganti alternatif dari allopurinol adalah kulit Melinjo.

Menurut peneltian yang dilakukan Sari et al (2019) ekstrak kulit dan daun melinjo dapat menurunkan kadar asam urat pada tikus jantan galur wistar yang diinduksi biji melinjo. Peneltian lain yang dilakukan oleh Wulandari et al, (2019) menyebutkan bahwa bahwa kulit melinjo mengandung flavonoid, saponin, alkaloid, dan polifenol dan daya inhibisi tertinggi terhadap aktivitas xantin oksidase diperoleh pada ekstrak etanol kulit melinjo muda mentah dan direbus yang pada konsentrasi 100 ppm setara dengan allopurinol 19,9 ppm. Kulit Melinjo diketahui mengandung pigmen antosianin berwarna merah. Disamping sebagai pewarna, antosianin juga bersifat antioksidan karena termasuk golongan flavonoid yang efektif untuk inaktivasi radikal bebas dan peroksil. Devina (2011) dan Suwito (2011) telah meneliti bahwa kulit buah melinjo berpotensi sebagai sumber antioksidan.

Antosianin memiliki masalah dalam penggunaannya, yaitu ketidakstabilannya dan mudah terdegradasi selama penyimpanan (Mahdavi et al. 2014)

Enkapsulasi adalah suatu teknik untuk melapisi atau menyalut suatu bahan aktif dengan lapisan dinding polimer sehingga menghasilkan partikel kecil berukuran mikro ataupun nano. Pelapisan atau penyalutan ini dapat melindungi bahan aktif dari kondisi lingkungan sekitar seperti cahaya, suhu, kelembaban, dan dari interaksi dengan zat lainnya. Ada beberapa teknik yang sering digunakan enkapsulasi pewarna alam, seperti spray drying, freeze drying, coaservation dan emulsi. Diantara semua teknik tersebut, spray drying yang paling banyak digunakan (Özkan dan Bilek 2014).

Dari uraian diatas perlu dilakukan penelitian untuk mengethui efek mikroenkapsulasi ekstrak kulit melinjo dan besaran dosis efektif yang tercapai terhadap penurunan kadar asam urat pada tikus jantan galur Wistar. ${ }^{[1]}$

II. METODOLOGI PENELITIAN

Bahan

Bahan tumbuhan adalah kulit melinjo yang diperoleh dari Kecamatan Grabag, Kabupaten Magelang. Bahan yang digunakan adalah etanol 70\%, Kalium Oksonat (Aldrich®), Jus hati Ayam, Allopurinol \& CMC Na. Hewan uji yang digunakan adalah tikus putih jantan galur wistar umur 2-3 bulan dengan bobot 150-250 gram diperoleh dari Laboratorium Farmakologi Stifar "Yayasan Pharmasi Semarang". Alat yang digunakan adalah Spuit $1 \mathrm{~mL}, 2,5 \mathrm{~mL}$ dan $5 \mathrm{~mL}$. Sonde oral tikus, timbangan, pengukuran asam urat dengan Microlab (B).

\section{Metode Penelitian}

\section{Uji Etik}

Penelitian ini dinyatakan lolos Etik oleh KEPK STIFAR "YAYASAN PHARMASI SEMARANG" dengan No Protokol :003/CNSW/KEPK/STIFAR/EC/X/2019

\section{Determinasi Tumbuhan}

Determinasi tumbuhan dilakukan di bagian lab Biologi STIFAR "YAYASAN PHARMASI SEMARANG" diperoleh hasil determinasi (Gnetum gnemon L.).

\section{Pembuatan ekstrak}

Kulit kering buah melinjo dilakukan perajangan dan dilakukan ekstraksi dengan etanol $70 \%$ (3 x 24 jam) secara maserasi pada suhu kamar. Untuk menguapkan pelarut diuapkan dengan dengan rotary evaporator pada suhu $50^{\circ} \mathrm{C}$ hingga diperoleh ekstrak kental.

\section{Skreening Fitokimia}

Dilakukan skreening fitokimia dilakukan untuk mengetahui kandungan senyawa sekunder dalam ekstrak kental. Uji skreening fitokimia meliputi uji Alkaloid, Flavonoid, Saponin, Tanin, Steroid dan Terpenoid.

\section{Uji Bebas Etanol}

Ekstrak kental dimasukan ke dalam tabung reaksi dan ditambahkan dengan asam asetat dan H2SO4 pekat, kemudian panaskan dengan api spiritus selama beberapa menit. Jika ekstrak sudah tidak tercium bau ester maka ekstrak tersebut sudah tidak mengandung pelarut etanol (Schoorl, 1998).

\section{Pembuatan Mikroenkapsulasi}

Pembuatan sediaan mikroenkapsulasi dengan Metode Freeze Drying. Maltodekstrin dilarutkan ke dalam aquadest. Ekstrak kulit melinjo juga dilarutkan ke dalam aquadest. Kemudian kedua larutan tersebut dicampur menjadi satu bagian, diaduk hingga homogen dan dicukupkan sampai 
$100 \mathrm{~mL}$. Larutan yang telah siap selanjutnya dibekukan pada suhu

$-40^{\circ} \mathrm{C}$ kemudian dikeringkan dengan freeze dryer. Mikroenkapsul yang terbentuk disimpan dalam wadah tertutup rapat dan terhindar dari cahaya.

\section{Uji Hiperurisemia Mikroenkapsulasi Ekstrak Kulit Melinjo}

Hewan uji dibagi menjadi 5 kelompok, masing masing kelompok berisi 5 hewan uji. Kelompok negatif diberikan $\mathrm{CMC} \mathrm{Na} 0,5 \%$, kelompok positif diberikan Allopurinol dosis 12,6 mg/kg BB, kelompok mikroenkapsulasi kulit melinjo dosis $100 \mathrm{mg} / \mathrm{kgBB}$, kelompok dosis $200 \mathrm{mg} / \mathrm{kgBB}$ dan kelompok dosis $300 \mathrm{mg} / \mathrm{kgBB}$. Sebelumnya hewan uji dipuasakan selama kurang lebih 18 jam sebelum pengujian, tetapi tetap diberi minum. Sebelum diberi perlakuan, semua hewan uji diukur kadar asam urat darah sebagai kadar awal (normal). Kemudian hewan uji dibuat hiperurisemia dengan memberikan kalium oksonat $300 \mathrm{mg} / \mathrm{kg}$ bb secara intraperitonial dan jus hati ayam secara per oral 2,5 $\mathrm{mL}$. Satu jam kemudian hewan uji diambil darah untuk diukur kadar asam uratnya. Selanjutnya hewan uji diberi perlakuan sesuai dengan kelompok perlakuan secara oral. Kadar asam urat dalam darah hewan uji diukur pada jam ke 2 dan 4 setelah pemberian perlakuan. Pengambilan darah melalui vena mata. Darah yang diperoleh dibuat serum dan diukur dengan menggunakan alat Microlab®.

Dari data kadar asam urat darah kemudian dihitung persentase penurunan :

\section{$\%$ Penurunan $=$ \\ kadar asam urat setelah induksi - kadar asam urat setelah perlakuan} kadar asam urat setelah perlakuan

Dari persen penurunan dilakukan uji statsitsik SPSS. Dilakukan uji normalitas dengan Saphiro Wilk. jika data tidak berditribusi normal dilakukan uji non parameterik kruskal walis dan diuji antar kelompok dengan (Mann Whitney). Jika data berdistribusi normal dilakukan uji One Way Anova dan Post Hoc.

\section{HASIL DAN PEMBAHASAN}

\section{Skreening Fitokimia}

Ekstrak kulit melinjo di lakukan uji skreening Fitokimia dan diperoleh hasil pada Tabel 1.

Tabel 1. Hasil Skrining Fitokimia Ekstrak Kulit

\begin{tabular}{cc}
\multicolumn{2}{c}{ Melinjo } \\
\hline Jenis Uji & Hasil \\
\hline Flavonoid & + \\
Alkaloid & + \\
& \\
Tanin & + \\
Saponin & - \\
Steroid dan & + \\
Terpenoid & \\
\hline
\end{tabular}

Dari Tabel 1. Menunjukan bahwa Ekstrak kulit melinjo mengandung senyawa metabolit sekunder berupa Flavonoid, Alkaloid, Tanin, Steroid dan Terpenoid.

\section{Uji Anti Hiperurisemia}

Pengujian aktivitas anti hiperurisemia dilakukan dengan mengamati \% penurunan kadar asam urat serum darah tikus setelah pemberian mikroenkapsulasi ekstrak kulit melinjo.

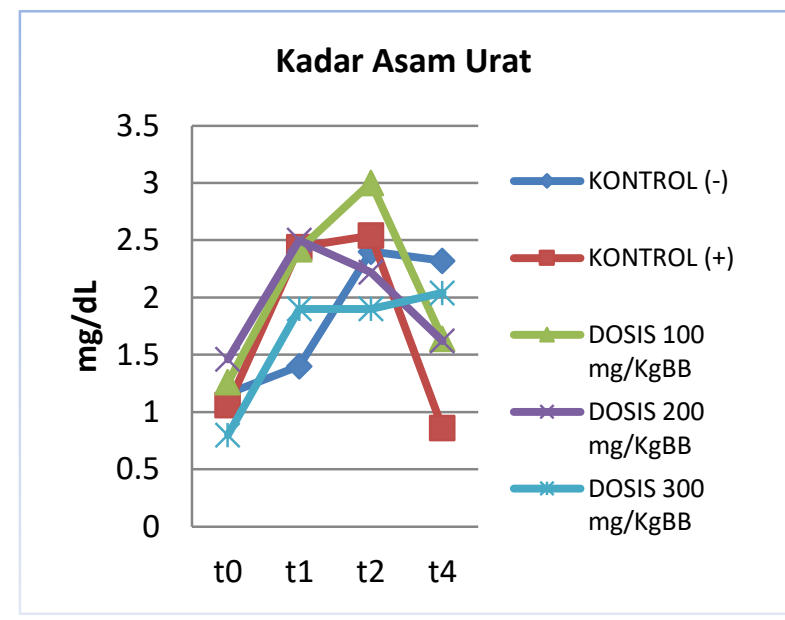

\section{Gambar 1. Kadar asam urat setiap kelompok perlakuan}

Keterangan :

$\mathrm{t} 0=$ kadar asam urat tikus sebelum induksi

$\mathrm{t} 1$ = kadar asam urat tikus 1 jam setelah diinduksi

kalium oksonat dan jus hati ayam

$\mathrm{t} 2$ = kadar asam urat 2 jam setelah diberikan perlakuan

$\mathrm{t} 4$ = kadar asam urat 4 jam setelah diberikan pelakuan.

Pada Gambar 1. Terlihat bahwa setelah dilakukan induksi tikus mengalami kenaikan kadar asam urat. Hal ini membuktikan bahwa induksi kalium oksonat dan jus hati ayam berhasil dalam menaikan kadar kadar asam urat. Asam urat merupakan produk akhir degradasi purin. Pada manusia asam urat diekskresikan di dalam urin karena manusia tidak memiliki enzim urikase, tetapi untuk mamalia asam urat dioksidasi lagi menjadi 
alantion sebelum diekskresi (Putra, 2007). Manusia mengubah nukleosida purin utama yaitu adenosin dan guanin menjadi produk akhir asam urat yang diekskresikan keluar. Adenosin akan mengalami deaminasi menjadi inosin oleh enzim adenosin deaminase. Fosforilase ikatan $\mathrm{N}$-glikosida inosin dan guanosin, yang dikatalisis oleh enzim nukleosida purin fosforilase, akan melepaskan senyawa ribose 1-fosfat dan basa purin. Hipoksantin dan guanin selanjutnya membentuk xanthine dalam reaksi yang dikatalisasi masingmasing oleh enzim XO dan guanase, kemudian xanthine teroksidasi menjadi asam urat dalam reaksi kedua yang dikatalisasi oleh enzim xanthin. Dengan demikian, XO merupakan tempat yang essensial untuk intervensi farmakologis pada penderita penyakit hiperurisemia (Rodwell et al., 2003).

Menurut Rahmawati \& Candra (2015) tikus tidak memiliki enzim ksantin oksidase sehingga tikus tidak mampu memetabolisme asam urat, tetapi pada tikus metabolisme asam urat dipengaruhi oleh enzim urikase. Tikus merupakan hewan tingkat rendah mempunyai enzim urikase yang dapat merubah asam urat menjadi alantoin yang dapat merubah asam urat menjadi alantoin yang lebih larut, sehingga asam urat tidak terakumalasi (Katzung, 2002). Enzim urikase yang dihambat oleh kalium oksonat menyebabkan asam urat akan tertumpuk dan tidak bisa dikeluarkan melalui urin (Katrin et al., 2009). Hal ini yang menyebabkan asam urat pada tikus meningkat.

Tabel 2. \% Penurunan Kadar Asam Urat

\begin{tabular}{|l|r|r|}
\hline \multirow{2}{*}{ Kelompok } & \multicolumn{2}{|c|}{ \% Penurunan Asam } \\
\cline { 2 - 3 } & \multicolumn{2}{|l|}{ Urat Jam Ke- } \\
\hline $\begin{array}{l}\text { Negatif (CMC Na } \\
0,5 \%)\end{array}$ & $-41.54^{\mathrm{a}}$ & $-33.74^{\mathrm{b}}$ \\
\hline $\begin{array}{l}\text { Positif (Allopurinol } \\
12,6 \mathrm{mg} / \mathrm{KgBB})\end{array}$ & $41.88^{\mathrm{a}}$ & 508.82 \\
\hline Dosis $100 \mathrm{mg} / \mathrm{kgBB}$ & $16.59^{\mathrm{a}}$ & 61.09 \\
\hline Dosis $200 \mathrm{mg} / \mathrm{kgBB}$ & $18.73^{\mathrm{a}}$ & $62.34^{\mathrm{c}, \mathrm{d}}$ \\
\hline Dosis 300mg/KgBB & $2.34^{\mathrm{a}}$ & -6.60 \\
\hline
\end{tabular}

Keterangan :

$\mathrm{a}=$ Tidak ada perbedaan signifikan One Way Anova Test $(\mathrm{p}>0,05)$

$\mathrm{b}=$ Berbeda signifikan $(\mathrm{p}<0,05)$ Mann Whitney Test dengan kelompok Positif

$c=$ Berbeda signifikan $(\mathrm{p}<0,05)$ Mann Whitney Test dengan kelompok Negatif

$\mathrm{d}=$ Tidak berbeda signifikan $(\mathrm{p}>0,05)$ Mann Whitney

Test dengan kelompok Positif

Menurut data pada tabel 2 menunjukan bahwa Allopurinol dan Mikroenkapsulasi Ekstrak Melinjo dapat menurunkan kadar asam urat. Diketahui dosis efektif didapat pada dosis $200 \mathrm{mg} / \mathrm{KgBB}$. Hal ini ditunjukan dengan hasil statstik dimana pada dosis $200 \mathrm{mg} / \mathrm{KgBB}$ berbeda signifikan $(\mathrm{p}<0,05)$ dengan kelompok negatif dan berbeda signifikan dengan kelompok positif $(\mathrm{p}>0,05)$.

Mekanisme Mikroenkapsulasi ekstrak kulit melinjo dalam menurunkan kadar asam urat belum diketahui pasti. Menurut Siregar et al, (2009) Kulit biji melinjo yang berwarna merah memiliki berbagai macam komponen atau senyawa yang berguna bagi tubuh dan dapat digunakan sebagai pewarna makanan alami. Komponen atau senyawa di dalam kulit biji melinjo yang berwarna merah adalah fenolik, flavonoid, likopen, vitamin $\mathrm{C}$, dan $\beta$-karoten. Sifat dari kulit biji melinjo yang berwarna merah dapat digunakan sebagai pewarna alami karena memiliki pigmen likopen dan $\beta$-karoten.

Salah satu metabolit sekunder yang terdapat pada mikroenkapsulasi ekstrak kulit melinjo adalah Flavonoid. Flavonol dan flavon memiliki efek penghambatan aktivitas santin oksidase paling tinggi pada planar dengan gugus 7-hidroksil. Gugus hidroksil dari chrysin dan luteolin pada C-5 dan C-7 dari kerangka flavon mempunyai kemampuan yang sangat kuat dalam menghambat aktivitas santin oksidase (Nagao et al., 1999). Senyawa lain yang mendukung aktivitas anti hiperurisemia adalah alkoloid, tanin, steroid dan terpenoid.

\section{IV.KESIMPULAN}

1. Mikroenkapsulasi Ekstrak Kulit Melinjo mempunyai aktivitas antihiperurisemia.

2. Dosis efektif antihiperurisemia Mikroenkapsulasi Ekstrak Kulit Melinjo adalah 200 $\mathrm{mg} / \mathrm{kgBB}$.

\section{UCAPAN TERIMA KASIH}

1. Ketua Sekolah Tinggi Ilmu Farmasi "YAYASAN PHARMASI SEMARANG"

2. Ketua LPPM Sekolah Tinggi Ilmu Farmasi "YAYASAN PHARMASI SEMARANG"

Atas pemberian dana hibah Penelitian Stifar "Yayasan Pharmasi Semarang" Tahun 2019

\section{REFERENSI}

[1] CC, B., Haloi, P., \& Barua, I. C. (2015). Gnetum gnemon linn.: A comprehensive review on its biological, pharmacological and pharmacognostical potentials. International journal of pharmacognosy and phytochemical research, 7(3), 531-539.

[2] Devina, Natalia, 2011, Optimasi Proses Ekstraksi Kulit Melinjo Merah (Gnetum gnemon L.) dan Pengaruh PH dan Cahaya 
Terhadap Aktivitas Antioksidan, Universitas Pelita Harapan

[3]

[4] Katrin, B. Elya, J., Amin, M. \& Permawati. 2009. Aktivitas ekstrak air daun gandarusa (Justicia gendarussa Burm.f) terhadap penurunan kadar asam urat darah mencit. Jurnal Bahan Alam

Indonesia. 7: 1

[5] Katzung BG. 2002. Farmakologi Dasar dan Klinik (terjemahan) Bagian Farmakologi Fakultas Kedokteran Universitas Indonesia, Salemba Medika, Jakarta, 487-493.

[6] Mahdavi, S. A., Jafari, S. M., Ghorbani, M., \& Assadpoor, E. (2014). Spray-drying microencapsulation of anthocyanins by natural biopolymers: a review. Drying technology, 32(5), 509-518.

[7] Murray, R. K., Granner, D. K., dan Rodwell, V. W. 2009. Biokimia Harper. Edisi 27. Terjemahan oleh Brahm U. Pendit. Jakarta : EGC.

[8] Nagao A., Seki M. and Kobayashi H., 1999, Inhibition of xanthine oxidase by flavonoids, Bioscience, Biotechnology, and Biochemistry, 63 (10), 1787- 1790.

[9] Ozkan, Gulay and Seda Ersus Bilek, 2014, Microencapsulation of Natural Food Colourants, International Journal of Nutrition and Food Sciences, 3 (3), 145-156

[10] Rahmawati and Candra K A., 2015, Pengaruh Pemberian Seduhan Daun Kelor (Moringa Oleifera Lamk) Terhadap Kadar Asam Urat Tikus Putih (Rattus norvegicus), Journal of Nutrition College, 4 (2), 593-598.

[11] Sari, N. K., Soemardji, A. A., \& Fidrianny, I. (2019). The Effect of Melinjo (Gnetum gnemon L.) Leaves and Melinjo Peel Extracts on Induced-Hyperuricemia Male Rats Model. Journal of Medicine and Health, 2(4).

[12] Siregar, T.M., Cornelia, M., Ermiziar, T., Raskita, S., 2009, The Study of Antioxidant Activity, Carotenoid and Vitamin C Content of Melinjo Peels (Gnetum gnemon L.), Perhimpunan Ahli Teknologi Pangan Indonesia di Seminar Nasional PATPI, ISBN 978-979-99570-5-4 